\title{
PARA VIVIR EN COBIJA: PREVALENCIA DEL MODO DE VIDA COSTERO EN ATACAMA
}

\author{
TO LIVE IN COBIJA: PREVALENCE OF THE COASTAL WAY \\ OF LIFE IN ATACAMA
}

\author{
Manuel Escobar M. ${ }^{1}$
}

\begin{abstract}
Utilizando los resultados de una etnografía y el trabajo de fuentes bibliográficas, se presenta un estudio principalmente descriptivo sobre el modo de vida de un habitante de la costa desértica, que practica la caza y recolección dentro de una lógica de comercialización libremercadista. Este fenómeno abre una reflexión acerca del vínculo con las sociedades tradicionales, mediante la idea de herencias culturales de larga data. El estudio se realizó en la localidad costera de Cobija, en la región de Antofagasta, la que se contextualiza históricamente mostrando la prevalencia de los modos de vida del desierto costero.
\end{abstract}

Palabras claves: etnografía, orillero, Cobija, desierto costero, herencias culturales.

\begin{abstract}
Using the results of an ethnography and the analysis of bibliographic sources, this article presents a mainly descriptive study of the way of life of an inhabitant of the desert coast who practices hunting and gathering within a free-market trading logic. This opens a reflection about the link with traditional societies, through the idea of long-term cultural heritages. The study was conducted in the coastal town of Cobija, in the region of Antofagasta, which by being historically contextualized shows the prevalence of the ways of life of the coastal desert.
\end{abstract}

Key words: Ethnography, orillero, Cobija, coastal desert, cultural heritages.

Primero el desierto. La cordillera de la Costa encima y una casa junto a la carretera. Al bajar por el camino aparecen las ruinas de adobe del siglo XIX. Es como pasar por formaciones rocosas pero con espacios para ventanas y puertas. En las primeras terrazas están las residencias de la mayoría de los habitantes, por lo general construcciones ligeras, hechas de tabiques de madera, cartones o planchas de calamina. Una bandera chilena se eleva sobre un techo y flamea desgarrada. En los alrededores, restos de objetos, pedazos de neumáticos, ruedas de bicicletas, fierros, maderas (Figura 1). No existen locales comerciales, no hay tendido eléctrico, y el agua potable la traen en camiones. No hay una plaza ni una calle principal donde se reúna la gente. Son pocos los que viven allí todo el año, la mayoría es población flotante que ha construido pequeños ranchos donde se quedan a trabajar por temporadas, períodos cortos o incluso van por el día, para luego volver a sus lugares de origen. La existencia es transitoria y precaria, volatilidad que no logra establecer un apego generacional con el lugar, la mayoría llega y vive prácticamente al día. No parece haber perspectivas de largo plazo, en una especie de complicidad con el mar que siempre ha estado ahí para recibir y abastecer. Cobija no tiene una comunidad que se sustente como tal. En general no hay actividades, aparte de las extractivas, que aglutinen y generen un sentido de pertenencia e identidad que impulsen a constituir una colectividad. La conexión a una idea comunitaria está dada por la participación en las dinámicas socioculturales de las ciudades aledañas, de las que varios son originarios, y donde por ejemplo pasan las festividades para estar con familiares o para ir a algún bar con amigos. Para muchos Cobija es solo un lugar de trabajo donde se obtiene el sustento. Tampoco hay vínculos, por lo menos directos, con las poblaciones originarias. La casa en que alojamos se ubica en el sector norte al lado de la playa, a unas dos cuadras de la caleta junto al camino antiguo, que fue parte de la carretera hasta el año sesenta. Cruzando el camino, en el murallón de la terraza que sigue hacia arriba, se encuentra una aguada llena de basura y que nadie utiliza. La vida que ahora genera son algunas cañas y pájaros que beben agua y se van rápido. Un poco más arriba hay dos grandes casas de veraneo, una amarilla y otra azul. Según conversaciones, sus

Austria 2140 dpto.703, Providencia, Santiago, Chile.mem1074@gmail.com 


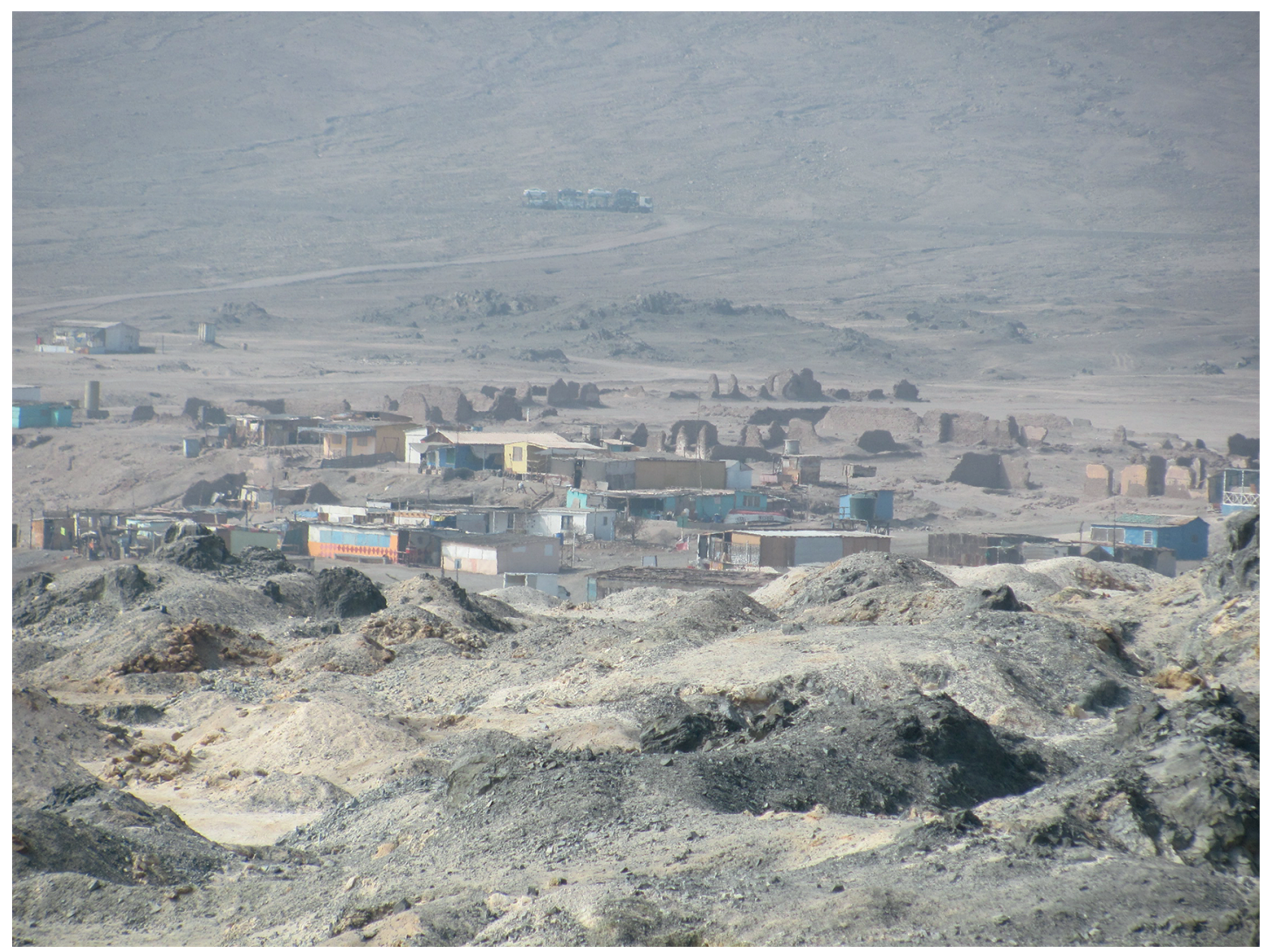

Figura 1. Ruinas y construcciones de Cobija

Ruins and buildings from Cobija.

dueños son de Tocopilla. Nunca las vi ocupadas, pero un día de la casa azul salía música clásica, que al mezclarse con el sonido del mar y del camino de tierra, desarticulaban la ensoñación paisajística e histórica. Botes flotan en la bahía, que la punta Castilla cierra y protege por el sur. En el varadero está un viejo muelle del que solo quedan en pie algunos fierros oxidados y vigas de madera, que ahora sirven para colgar los pescados de la faena diaria. Al frente está la sede del sindicato, en una deteriorada construcción antigua que les fue cedida por la Gobernación Marítima y que originalmente, se cuenta, era parte de la aduana del decimonónico puerto.

\section{Puntos de Partida}

Desde un inicio el objetivo de la etnografía realizada en Cobija fue conocer los saberes y formas de subsistencias actuales de sus habitantes, teniendo como referencia lo documental. La bibliografía más descriptiva sobre las formas de subsistencia (Bittmann 1977, 1979, 1984a; Larraín 1978; Latcham 1910; Llagostera 2005) muestra pescadores, mariscadores y cazadores de guanacos y lobos marinos. Destacado en la mayoría de los documentos, el lobo hacía parte de la dieta y era usado para la confección de varios artefactos característicos. Ahora cazar lobos es ilegal. También desapareció la caza del guanaco, según los relatos, durante los años sesenta del siglo pasado. En cuanto a la pesca, la incorporación de técnicas e instrumentos nuevos la han transformado; sin embargo, ahora en Cobija casi no se pesca. Los entrevistados lo adjudican a una intensa Corriente del Niño en los años ochenta y a la pesca industrial que arrasa con el fondo marino y provoca la disminución de peces y que económicamente no sea beneficioso. Es así como el buceo se ha convertido en la actividad más importante y eje del funcionamiento de la caleta. Este se realiza de dos maneras, una conocida como "a resuello", técnica de apnea en donde un buzo puede trabajar 
solo, fundamentalmente por los sectores de orilla, y la otra con compresor de aire, equipamiento y técnica que aparece en la década de 1960 y que se practica en bote, donde se lleva el compresor. Se necesita además del buzo un Tele ${ }^{1}$, que maniobra el bote y monitorea a la máquina y al buzo, que baja conectado al compresor a través de una manguera. Esto implicó una mayor comercialización, que junto al volumen de lo capturado, se alejaban de la relación más directa con el medioambiente que buscaba para esta investigación. Tampoco escogí a los buzos a resuello para desarrollarla, pues su relación con el mar, por lo menos los que conocí en Cobija, era muy utilitaria. Llegaban en automóviles, extraían y volvían a sus casas, mayoritariamente en Tocopilla. Es por eso que opté por trabajar con un orillero ${ }^{2}$, don Manuel Olivares, pues a pesar de que también vendía sus productos, se dedicaba a la caza y a la recolección por la costa con técnicas bastante elementales, acercándose más a las formas de subsistencia descrita en los documentos. A diferencia del resto de trabajadores de mar, don Manuel vivía en Cobija y por lo tanto su relación con el lugar era continua. Su día giraba en torno a las subidas y bajadas de la marea -indicador de cuándo trabajar-, arreglar su vivienda y artefactos, alimentar sus perros, hacer fuego para cocinar, o leer un periódico viejo. Desde un punto de vista, se podía concebir que las bases de su modo de vida eran de cazador recolector. Recolector de huiros (algas) y de mariscos, y cazador de pulpos (Octopus mimus), que era la actividad que guiaba y más remuneraba su trabajo. Es cierto que las caracterizaciones generales de los cazadores recolectores se basan en lo grupal y no en lo individual (p.ej. Sahlins 1983 [1974]; Service 1973 [1966]); comúnmente la banda es la entidad mediante la cual se hacen las descripciones, ya que es la organización que ha basado su reproducción social y cultural en un modo de vida cazador recolector. Sin embargo, la reflexión aquí presentada considera al modo de vida cazador recolector como una práctica de subsistencia, que puede presentarse en distintas entidades socioculturales, y que al interactuar en ellas para alcanzar su viabilidad genera formas particulares de existencia, que no lo reducen solo a una manera de producir. Algo similar es lo que propone desde su perspectiva Sahlins (1972 [1968]:12-15), respecto de las sociedades cazadoras recolectoras que gestaron una cultura tribal, que en forma regular se ha considerado propia de pastores o agricultores.
Service (1973 [1966]) propone algunas características comunes. Lo más obvio y tal vez lo más crucial, el nomadismo. Esta a su vez genera otras, como la simplicidad y la pobreza de la cultura material, debido a la necesidad que tienen de llevar consigo sus pertenencias. Asimismo, la condición nómade implica que el tamaño de la comunidad sea restringido, constituyendo una sociedad simple y estableciendo a la familia como eje de la organización social y cultural. Por su parte Sahlins (1983 [1974]) contrasta los supuestos de la sociedad de mercado con la de los cazadores recolectores, que sería una sociedad de la opulencia siguiendo las premisas de un camino Zen: "las necesidades materiales humanas son finitas y escasas y los medios técnicos, inalterables pero por regla general adecuados" (Sahlins 1983 [1974]:14). Junto a esta manera de describir a los cazadores recolectores -la mejor según el autor-, agrega otra fundamental; la cantidad de trabajo es bastante menos que la de agricultores o trabajadores industriales. "Los trabajos de subsistencia de los cazadores son intermitentes, esa es su característica, un día de trabajo y un día libre" (Sahlins 1983 [1974]:50).

Para establecer un modelo comparativo, que pueda mostrar las similitudes con don Manuel, tomé de estas características lo individualizable. Sus necesidades materiales en general son finitas, no hay un interés material mayor a sus necesidades básicas, a pesar de que existen opciones a las que podría intentar acceder. Es cierto que compra alimentos y otros productos con el dinero que gana con sus ventas, pero el alcance que tiene ese consumo es bajo, pudiendo considerarse parte de sus necesidades finitas. Esto mostraba que podía establecer conexiones con el libre mercado, sin necesidad de depender por completo de él, y que las condiciones de ese intercambio estaban sujetas a la forma en que decidía hacer su vida. Sin embargo, mi interpretación era que aquello, si bien implicaba autonomía, era posible en la medida en que sus prácticas elementales eran expresión de unas estructuras que lo antecedían. Justo esa idea me permitía concebir el modo de vida cazador recolector desértico costero y las agencias vinculadas a él. Es necesario precisar que por modo de vida entiendo una configuración basada en estructuras simbólicas y cognitivas generadoras de prácticas, como el habitus de Bourdieu (2007 [1980]), y no como sinónimo de cultura. 
Respecto del nomadismo, si bien don Manuel tenía una vivienda fija, era relativo, ya que continuamente estaba viajando a Tocopilla o Antofagasta por vínculos familiares y comerciales, donde se quedaba muchas veces por más de un día. Asimismo, tenía una alta movilidad en su trabajo por la costa, recolectando y cazando hacia el norte y sur de Cobija. Sobre esto, Sahlins comenta que una desventaja de la praxis de la caza y recolección es la inminencia de una disminución de los ingresos, debido al agotamiento de los recursos. "La solución es, por supuesto, dirigirse a otro sitio. De ahí la primera y fundamental contingencia de la caza y la recolección: exige movimiento para mantener una producción ventajosa" (Sahlins 1983 [1974]:47). En este sentido, el trabajo de don Manuel era asimilable a la necesidad de movimiento -fundamento principal del carácter nómada planteado por Service (1973 [1966]:16)-, ya que como expuse, su trabajo se basa en los recorridos que hacía por la costa cazando y recolectando. Estos recorridos se realizan según el desgaste que tengan los lugares de captura (rocas y cuevas), y eso depende de la cantidad de veces que él ha ido, y de la cantidad de personas que también hayan trabajado en esos sectores. Además siempre buscaba una mejor zona, donde la corriente hubiera permitido el ingreso de los pulpos (Octopus mimus) y que varara huiro. Ligado a esto se encuentra la cantidad de tiempo de trabajo. Diariamente alrededor de 4 horas, y según las condiciones climáticas o personales, puede ser que algunos días no trabaje.

También se asemejan sus requerimientos de medios técnicos, ya que son bastante elementales (fierros, gomas, recipientes de plástico, etc.) y de fácil acceso, la mayoría obtenidos de los residuos de otras actividades, o por medio de sus conocidos. Cada vez que alguna de sus herramientas se deteriora, como la bicicleta, una lámpara o sus instrumentos de caza, busca entre las piezas que guarda de aparatos en desuso, e intenta repararlos. Esto es destacable, porque muestra la autonomía que tiene dentro del contexto tecnológico con que se rodea, y al igual que otro cazador tomaba una piedra para transformarla en punta de flecha, él recoge un pedazo de goma y un fierro para convertirlos en herramientas de caza.

$\mathrm{Al}$ mismo tiempo su producción se insertaba en una cadena de comercialización que incluía la industria conservera y la de exportación de algas, como también las ventas que hacía él mismo. Además, sus relaciones sociales no se limitaban a su cotidiano costero, sino que con cierta continuidad se integraba a redes sociales con familiares y amigos, en Antofagasta y Tocopilla. Se delineaba entonces el siguiente escenario. El sujeto participaba pero no respondía a todos los marcos establecidos por la sociedad contemporánea y su influjo neoliberal, y esa alternativa se sustentaba en unas prácticas que al conectarlas al pasado parecían configurar un modo de vida propio e histórico del desierto costero atacameño.

Llegado a ese punto, había que buscar la manera de interpretar el fenómeno. Por una parte, los aspectos más directamente económicos, en tanto práctica productiva local articulada a la economía-mundo capitalista, sugerían un análisis como el que propone Wallerstein (2006), que develara sus conexiones con el sistema-mundo moderno, para comprender su lugar en los circuitos de comercialización y las implicancias para su protagonista. $\mathrm{O}$ incluso, desarrollar un análisis más específico en términos de exclusión social. Sin embargo, mi atención estaba puesta en las prácticas y conocimientos que sustentaban el modo de vida del orillero y el potencial vínculo con herencias culturales de larga data-como también lo hace desde otra perspectiva el enfoque de los paisajes culturales (Castro et al. 2012)-, ya que posibilitaban el conocimiento de una dimensión, obviamente articulada a lo económico, pero que podía ser descrita paralelamente, pues constituía al sujeto en aspectos de su experiencia que me parecían fundamentales, y que al mismo tiempo era lo que condicionaban su inserción en el sistema capitalista.

\section{Breve Retrospectiva de la Ensenada}

Algo distingue radicalmente a Cobija de las caletas cercanas. Sus ruinas no solo evocan la presencia de los habitantes del siglo XIX, sino que parecen abrir una puerta a su pasado, del que se ha escrito bastante. Desde mediados de la década de 1970 Bente Bittmann lo estudió intensivamente, desarrollando un programa de investigación que estableció bases para lo que vino luego (Bittmann 1979, 1980, 1983, 1984a, 1984b), e inscribió una de las imágenes más particulares de la memoria cobijana, una mujer danesa recorriendo la caleta. Así lo cuentan los integrantes de la familia Pinto, los habitantes más antiguos de Cobija y amigos de la investigadora, especialmente la madre y abuela, la señora Blanca, quien recuerda con gracia que a ella 
le decía White y le escribía desde Europa cuando ya no pudo volver a Chile. También la conoció don Manuel Olivares, quien la veía siempre con un perrito. Él, a mediados de 1980, comenzó a cazar pulpos para venderlos a las conserveras que empezaban a comprarlo, pero se había instalado definitivamente en la caleta a finales de la década de 1970. A mediados de la década anterior habían llegado a Cobija los trajes de goma y las máscaras para bucear, lo que permitió a los entonces niños de la familia Pinto trabajar bajo el agua sin dañarse los ojos, que era la forma en que habían aprendido con viejos costeros de lugares cercanos como Hornito o Michilla, que mariscaban en Cobija. Aprendizaje de una tradición tan diferente a las herencias culturales de sus padres, pues la señora Blanca junto a su marido y a su hijo Danilo de ocho meses -hoy el hombre mayor de la familia- llegaron en 1950 desde Ovalle. El padre, como muchos, venía tras la minería y se instaló allí para explotar las vetas de los cerros inmediatos. Cuando llegaron, en Cobija solamente vivían un cuidador del galpón de una empresa minera junto a otro viejo (Escobar 2007:112). Recuerdo que cierra la memoria oral y que prefigura una etapa en el devenir histórico de las prácticas costeras, que conecta al siglo XIX con el XX, mediante las primeras generaciones de costeros y los aprendices iniciales de la segunda mitad del siglo, que reciben, recrean y transmiten a las nuevas generaciones. Para Bittmann (1977:115), los portadores de lo que designó como supervivencias de conocimientos sobre los recursos marinos, las técnicas y métodos de explotación.

Luego, unas fotografías en el libro de Arce (1997 [1930]), seguramente de la segunda mitad de los años 1920. En una aparece un automóvil y gente alrededor -destaca un hombre de traje blanco-, junto a una casa antigua que aún tiene un gran farol colgando sobre la puerta de entrada. El texto dice que son las ruinas de Cobija, a pesar de que esa casa no se ve desmantelada. Es en otra fotografía donde aparecen los mismos altos y desnudos muros de adobe que se reconocen hoy. Hay una tercera imagen tomada desde el muelle, que aun se ve entero, con un bote que cuelga desde uno de sus costados aparentemente en uso y un hombre de aspecto marino. Ambas, hacen pensar que el abandono de Cobija en ese momento no es total. En realidad, al parecer el otrora puerto nunca quedó completamente abandonado. Salvador González, que entre 1918 y 1920 fue cura de Gatico, localidad minera a unos pocos kilómetros más al norte, cuenta en Norte Bravo (Flores et al. 2005:285-386) que organizaba excursiones a Cobija. Según él, los únicos habitantes era la familia Acosta, compuesta de tres mujeres, dos hermanas y la hija de una de ellas, que los invitaban a comer suculentas comidas marinas. ¿Pero quién suministraba los ingredientes? Un documento de 1911 registra 3.000 habitantes (Bittmann 1980:91), número que parece impreciso cuando se sabe que en 1908 otro religioso informa que el puerto está desierto, pues solo quedan unos cuantos habitantes y un buen templo, por lo que había ordenado trasladar a Gatico las dependencias eclesiásticas (Flores et al. 2005:164). Comentarios sobre la cualidad de pueblo abandonado, que se entiende apuntan a la concepción formal de lo que un pueblo es y no a la ausencia total de gente. Así parece entenderlo Bermúdez (1967), quien comenta que en ese inicio de siglo continuó la erradicación de sus habitantes hasta no quedar una población normalmente establecida, sirviendo como refugio transitorio de pirquineros -seguramente más de alguno depositario de la, en ese momento, alicaída tradición desértico-costera-, agregando que en 1885 la población se había reducido a 429 habitantes.

A las 8 de la mañana del 21 de marzo de 1879 los buques de la marina chilena dirigidos por el contralmirante Williams, fondeaban en la bahía de Cobija o Puerto Lamar y a las 9 lo ocupaban sin resistencias (Vicuña 1880:328). Así acababa la soberanía boliviana en la costa atacameña. Un par de años antes, el 9 de mayo de 1877, alrededor de las 8 y media de la noche, comenzó un terremoto devastador seguido de un maremoto. Muchas edificaciones se derrumbaron y a pesar que los gritos de que el mar se salía permitieron a muchos arrancar a los cerros, 44 personas fueron tragadas por el océano, incluyendo una familia completa de 14 miembros (Arce 1997 [1930]:357). En el mismo libro hay una foto donde a bastante distancia de la costa dos hombres posan rodeados de escombros. A comienzos de esa década el descubrimiento del mineral de Caracoles había generado expectativas para el puerto, pero no duraron mucho, pues se encontró una vía mejor hacia Antofagasta, por donde se comenzaron a hacer casi la totalidad de los embarques (Bravo 2000:50-51). Otro duro golpe a las autoridades bolivianas, que intentaban la recuperación de Cobija, luego que en 1869 una epidemia de fiebre amarilla matara mucha gente, incentivando la emigración hacia la naciente 
Antofagasta, proceso que había comenzado el año anterior debido al terremoto de 1868 (Bermúdez 1966:64). Movimiento poblacional impresionante, si se consideran los datos que fijan en esta década el mayor desarrollo del puerto, calculando 5.000 habitantes para 1867 (Bermúdez 1967). En septiembre de ese año el pionero Chango López llegaba a Cobija en su bote "Halcón" desde Peña Blanca, actual Antofagasta, con la primera remesa de los minerales de cobre que había descubierto (Bermúdez 1966:68). Los altos precios habían producido un auge minero desde mediados de siglo, posicionando a Cobija como puerto de embarque de muchas compañías, como la Artola Hnos. que explotaba el mineral de San Bartolo cercano a San Pedro de Atacama (Aldunate et al. 2008). Sin embargo, las dificultades no solo eran telúricas y sanitarias. En 1853 Philippi (1860:23) encuentra unos indios de Atacama en Paposo, quienes habían tenido que ir a esa localidad a intercambiar hojas de coca por pescados y mariscos secos, pues Cobija había sido ocupada por el ejército peruano. Referencia que muestra la vigencia de la producción marina local. Por su parte Cajías (1975:45-65) indica que el mayor apogeo del puerto se da en la década de 1850, alcanzando 2.000 habitantes, lo que habría comenzado a gestarse por el descubrimiento de la utilidad del guano al empezar la década anterior. En esos años, 1840 y 1841, el puerto recupera el movimiento y la población que había perdido como consecuencia de la guerra de la Confederación contra Chile y Argentina, el establecimiento de Arica como aduana común para el sur de Perú y Bolivia, así como también la invasión del general peruano Salaverry, que en 1835 destruyó todos los edificios del gobierno. A mediados de 1832 las autoridades anunciaban que la construcción de las nuevas aguadas se volvían insuficientes. Problema constante, aunque en 1830 lo habían logrado solucionar; mismo año en que el naturalista D'Orbigny visita Cobija, describiendo a los indígenas y sus balsas de cuero de lobo, destacando que cada casa comercial tenía su balsero titular para el cabotaje de mercancías prohibidas (D’Orbigny 1945 [1844]; III:936). Flujo comercial evaluado por el gobierno de Santa Cruz, que a mediados de 1829 decreta la autonomía de la provincia de Atacama, designando a Cobija como capital (Cajías 1975:35). Habían pasado ya dos años desde que finalmente se iniciara su habilitación formal, en vez del 1 de enero de 1826, establecido en el decreto firmado por Bolívar en diciembre de 1825 , que designaba como puerto boliviano a Cobija, renombrado como Lamar en honor al mariscal José Lamar. La elección fue hecha basada en la recomendación del coronel O'Connor, a quien se le ordenó recorrer Atacama y hacer un informe sobre el mejor lugar para un puerto. En Cobija encontró a un cuidador de apellido Maldonado, cochabambino, quien le dijo que vivían ahí trece familias, pero que habían arrancado a Mejillones o Tucupillo [sic], a esperar que pasara una peste de viruela (O'Connor 1928:271). Descripción que permite concebir el gran cambio producido durante el siglo XIX, como también lo demuestran los resultados de una revisita en Atacama efectuada en 1804, que registra en Cobija tres originarios y tres forasteros con tierras y dos cholos con tierras, escasa población que estaba a cargo de un gobernador cacique (Hidalgo 1978). Sin embargo, es interesante saber que el tráfico formal de productos ya funcionaba. Una compañía chilena en 1796 lleva mercancías de Coquimbo a Potosí por la ensenada. En su solicitud de permiso se comprometían a cambio a construir un estanque de agua, una bodega y una capilla si no la hubiere, o reparar la existente. Se les concedió el permiso por 8 años (Bermúdez 1962). Otra revisita en 1792 registra 10 originarios, 9 cholos con tierras y un forastero (Hidalgo 1978). En 1791 Cañete y Domínguez publica su guía de la provincia de Potosí, donde a base de informes describe el Puerto de la Magdalena de Cobija y a sus infelices habitantes, argumentando en contra de incentivar el comercio y la pesca de ballena (Cañete y Domínguez 1791:268-273). Cuestión que analiza Hidalgo (1983), en relación con el informe hecho por el Dr. De Arze sobre su visita al puerto en 1786, interpretando las afirmaciones de Cañete y Domínguez como una respuesta indirecta a De Arze, que abogaba por reforzar el tráfico entre Potosí y Cobija -rivalidad constante con Arica-, y por estimular la caza de ballenas. Discusión que remite a las especializadas prácticas marítimocosteras de ese período. En 1776 la Audiencia de Charcas pasó a formar parte del Virreinato de Buenos Aires y el corregimiento de Atacama se convierte en uno de los seis partidos que dependen de la Intendencia de Potosí. Partido dividido en Atacama la Alta, con cabecera en San Pedro, y Atacama la Baja cuya cabecera es Chiuchiu y Cobija su pueblo costero (Cajías 1975; Castro 2009). Alrededor de un año antes de este cambio administrativo, al constatar la falta de agua para las embarcaciones visitantes, el entonces corregidor de Atacama 
Argumaniz, hizo entubar las vertientes dirigiéndolas a una sola cañería subterránea (Hidalgo 1983; 2009). Escasez destacada también por Juan y Ulloa en 1735, que en expedición científica informan que Cobija se componía de ranchos de indios pescadores muy pobres y que su escasa agua era de mal gusto y salobre (Juan y Ulloa 1826). Con anterioridad se sabe del puerto y sus habitantes por tres franceses. El ingeniero Frezier (1902 [1716]), que llega en 1713 a la rada aunque no desembarca, el sacerdote Feuillée (1714) que en 1710 está solo unas horas, dejando valiosas descripciones de los indígenas, y en 1707 un comerciante de apellido Bauver o Bervau -según la autora que sacó a la luz el documento (Pernoud 1990 [1942])-, que desembarca para viajar al interior donde el gobernador de Atacama, relatando que solo encontró al criado negro del cura, quien le dice que los habitantes -según el francés aproximadamente 300 personas $^{3}$ - al verlos habían arrancado a los cerros pensando que eran piratas. Los tres franceses destacan de los costeros sus viviendas, alimentación, artefactos, actividades y el consumo e intercambio de pescado, lo que permite delinear su modo de vida. Otra revisita fue aplicada en 1683; reconoce a Cobija como uno de los cuatro ayllus de Atacama la Baja y empadrona a 125 indígenas, aunque 14 de ellos aparecen como ausentes, casi todos en puerto Loa (Hidalgo et al. 1992). Destacan algunos apellidos, como el de la mujer del cacique principal llamada María Guacachu, pues hoy los costeros le dicen guacacho o guacache al pelícano (Pelecanus thagus), o el de Domingo Chulapo que también resuena en el diálogo costero actual, pues a los grandes lobos marinos (Otaria flavescens) les dicen callapo. De los ausentes sobresale un apellido seguramente mapuche, Milipillán, que permite reflexionar sobre las inmigraciones tempranas y la capacidad de inserción que ofrece el modo de vida costero. Hay también un indígena llamado Francisco Otal, igual que un sacerdote, evangelizador y extirpador de idolatrías, que ejerció en Atacama desde 1620. Victoria Castro, quien trabajó su Probanza de Méritos, plantea que el registro de personas de raza negra e indígenas con su apellido probablemente se deba a que se los haya "prestado" el párroco (Castro 2009:157). El cura Otal se relacionó mucho con los costeros, incluso logrando aprender su lengua, cuestión muy destacada por otros funcionarios y que le otorgó un estatus excepcional. Tanto, que en 1626 para impedir que abandonara la región se le asignaron seis indígenas que pescaran para él y así pudiera mejorar sus ingresos con la venta de pescado (Castro 2009:548-549). También hay noticias sobre él en el Libro de Varias Ojas [sic] de la parroquia de Chiuchiu, que compila registros del siglo XVII, como que en Cubija [sic] en 1615 se le puso óleo y carisma a la hija del mestizo Carlos Barroso e Ysabel Chayllon, y que el padrino fue el español Miguel Cermeño (Casassas 1974:111) ¿Qué hacían ahí esas personas no indígenas ni eclesiásticas? Quizás dedicados al tráfico colonial con el interior, que una carta fechada en 1591 muestra que se inició tempranamente. Allí se informa sobre el conflicto entre Juan Segura, corregidor de Atacama, y Juan Velázquez Altamirano su antecesor en el cargo, centrando la discusión en las irregularidades y monopolio que este último sostenía con el tráfico de pescado de Cobija a Potosí (Martínez 1985). Unos años antes, en 1587, se habría fundado Cobija bajo el nombre de Santa Magdalena de Cobija, para servir de refugio a navegantes en ese tramo costero (Fifer 1976:53). Y antes de ese nombre, una carta escrita al virrey del Perú en 1581 describe la provincia de los Lípes e informa sobre la ensenada de Atacama que es donde está el puerto y donde viven 400 indios pescadores que solo se sustentan de pescado (Lozano Machuca (1885 [1581]), siendo esta supuestamente la primera referencia documental a Cobija, aunque para algunos autores es cuestionable que sea efectivamente el puerto de Atacama ${ }^{4}$. Como Latcham (1910:20), que lo sitúa un poco más al norte, aunque sin precisar su ubicación, o Cajías (1975:41), quien escribe que probablemente el llamado puerto de Atacama haya sido en realidad Tocopilla. Divergencia interesante al cerrar este relato, que desea principalmente mostrar cómo a pesar de los intentos por adecuar la ensenada a los requerimientos externos, trenzados en la historia, un modo de vida y unas prácticas propias del desierto costero, han logrado prevalecer.

\section{Orillero en Cobija}

Llegando a la caleta apareció un hombre que saludó amistosamente. Estaba en un comedor que era casi al aire libre. Un techo lo cubría del sol aunque en ese momento estaba nublado y dos separaciones hacían de murallas. Una era un mueble donde había algunas fotos, un reloj y una radio que funcionaba conectada a una batería de auto. La otra, un tabique de madera donde había pegadas fotos de modelos 
televisivas en traje de baño, una bandera de Cobreloa (equipo de fútbol de Calama), unos dibujos de Jesús, la Virgen María y un calendario. Conversamos un rato y luego ofreció pescado. Agarró un pejeperro (Semicossyphus darwini) que tenía colgado y comenzó a filetearlo. Mientras tanto contó que se dedicaba a orillar y explicó de qué se trataba. Lo escuché atentamente y entendí que esa era la dirección que debía tomar. Sin embargo, después de las conversaciones que tuvimos y de las varias horas que pasé con él, lo que motivó mi interés por conocer la forma en que vivía, no fueron únicamente sus formas de subsistencia que lo ligaba a los habitantes tradicionales de la costa desértica, sino como ya he escrito, que representara la coexistencia de esa dualidad o tránsito entre aspectos cazadores recolectores y la vida contemporánea. Sentarme a conversar con él acerca de las sesiones fotográficas de Tunick ${ }^{5}$ o sobre las canciones que bailaba en alguna fiesta tocopillana y después verlo cazar pulpos, recolectar mariscos y luego convertirlos en dinero, eran experiencias que parecían tan ajenas pero que delineaban una situación antropológica interesante de describir y difundir.

\section{Datos biográficos}

He considerado relevante presentar algunos elementos de su biografía, pues los recorridos que muestran eran bastante paradigmáticos de todo un proceso acontecido en esta región. Manuel Olivares nació en Tocopilla en 1946. Sus padres se habían conocido en Gatico, localidad cercana a Cobija. Su papá era originario de Ovalle y su mamá gatiqueña. Sin embargo, los padres de ella no eran de Gatico, el padre era argentino y la madre al parecer de Tierra Amarilla (localidad de la actual región de Atacama). A los 14 años vive con unos tíos en la oficina salitrera Vergara. A los 16 vuelve con su familia a Gatico y se queda un par de años. No continúa estudiando, trabaja. Su madre y hermanos se van a Antofagasta y su papá a Tocopilla. Queda solo en Gatico. Luego vuelve a la oficina Vergara pero esta vez a casa de una tía, tiene 17 años, aproximadamente. A los 19 hace el Servicio Militar en Calama, entre 1965 y 1967, sale a los 21. Vuelve a Gatico, vive en hostales y trabaja de orillero un par de años. En 1969 comienza una estadía en Antofagasta. Llega a vivir a casa de una hermana y después en la casa de su madre. Está 10 años en Antofagasta. Trabaja en CORFO de ayudante mecánico y en la Coca-Cola, entre otros oficios. En 1977, aproximadamente, vuelve a Gatico por un tiempo corto junto a su hermano Ricardo. Se van a las ruinas de la planta Cobija (de minería) que está al norte de la caleta y viven ahí un tiempo. Entre 1977 y 1978 llegan a Cobija, vienen detrás de los huiros. Está un periodo en transición entre Cobija y Antofagasta, hasta que en 1979 se instala definitivamente en la caleta, aunque conservando su movilidad.

\section{Cazar, recolectar, convertir en dinero}

\section{Trabajo y equipo}

Orillar consta de cuatro actividades. Tres de ellas tienen una finalidad comercial, lo que no implica que no tengan otras significaciones. Estas son la recolección de huiros negro, palo y canutillo (Lessonia nigrescens, L. trabeculata, Macrocystis pyrifera) (Figura 2), la extracción de mariscos y la caza del pulpo (Octupus mimus). La cuarta es la pesca con lienza realizada a veces, pues la obtención es baja y no se vende bien; su valoración está dada más por aspectos recreativos y alimenticios. Al orillar va mariscando, pulpeando y juntando huiros en los mismos recorridos. El equipo se puede dividir en herramientas comunes para todas las actividades y herramientas específicas para cada una de ellas. Casi todo el equipo es fabricado y reparado por él mismo. Dentro de las herramientas comunes está la bicicleta, para llegar a las playas más lejanas, cargar con el resto de los materiales y llevar lo capturado. También la ropa. Pantalón de algodón, un par de poleras para el frío, gorro de lana y para los pies que están la mayor parte del tiempo en el agua, un par de calcetines, soquetes de goma igual que los buzos y unas alpargatas o changas hechas de perlón y tejidas por él mismo. Completa esta parte del equipo el chinguillo, malla que se amarra a la cintura donde deposita lo capturado. Las herramientas específicas son: para la recolección de huiros simplemente hace pequeños montones, y les coloca piedras con manchas blancas, que es su marca. Para mariscar, es una la herramienta, el chope. Fierro de unos $30 \mathrm{o} 40 \mathrm{~cm}$ que tiene una punta curva y la otra levemente doblada. Se usa como palanca para arrancar los mariscos (Figura 3). En cambio el pulpear requiere de tres fierros. Uno es el cangrejero, fierro de unos $70 \mathrm{~cm}$ con una punta aguzada y la otra con empuñadura. Sirve para cazar 


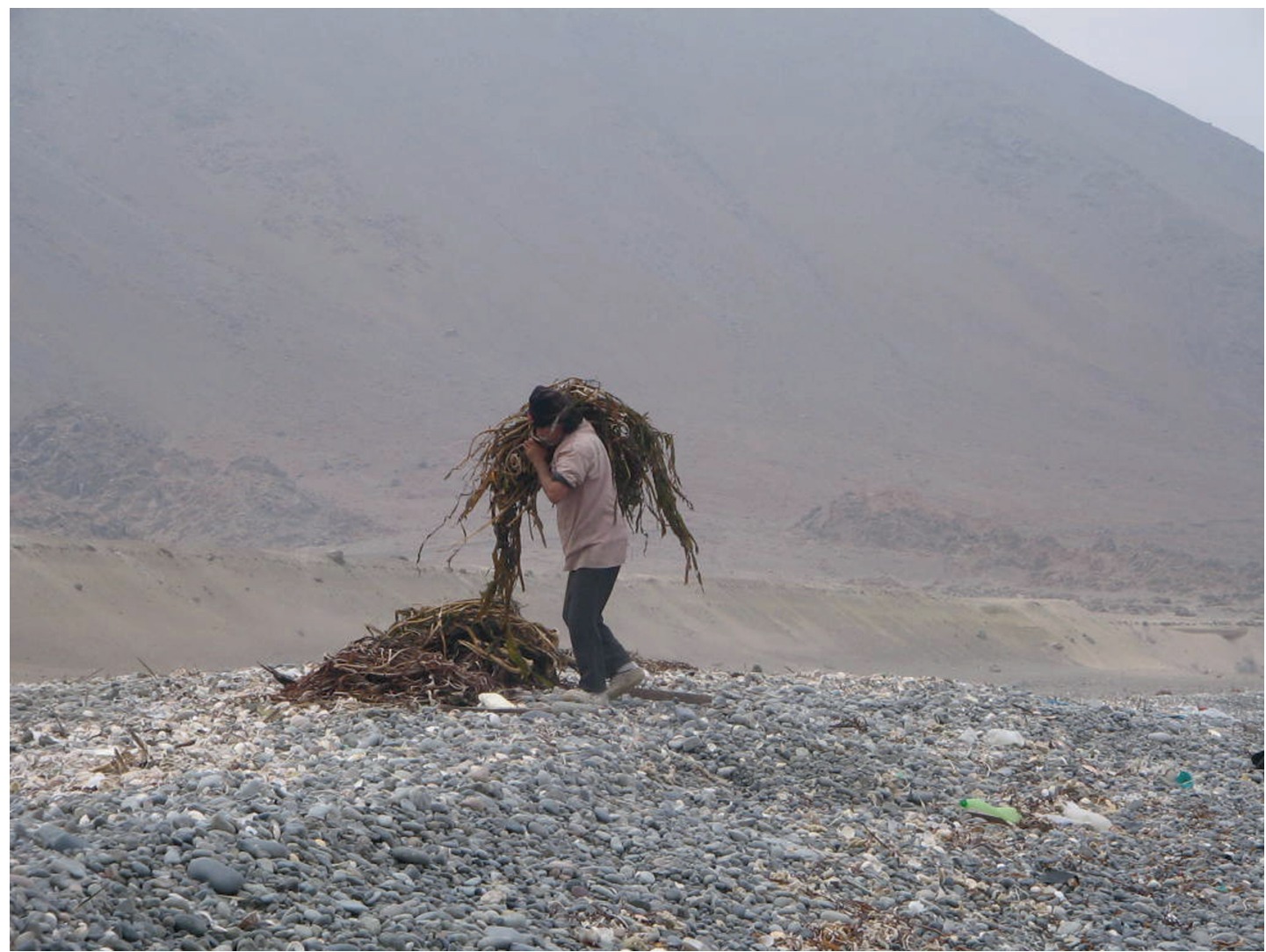

Figura 2. Recolectando huiros.

Gathering huiros.

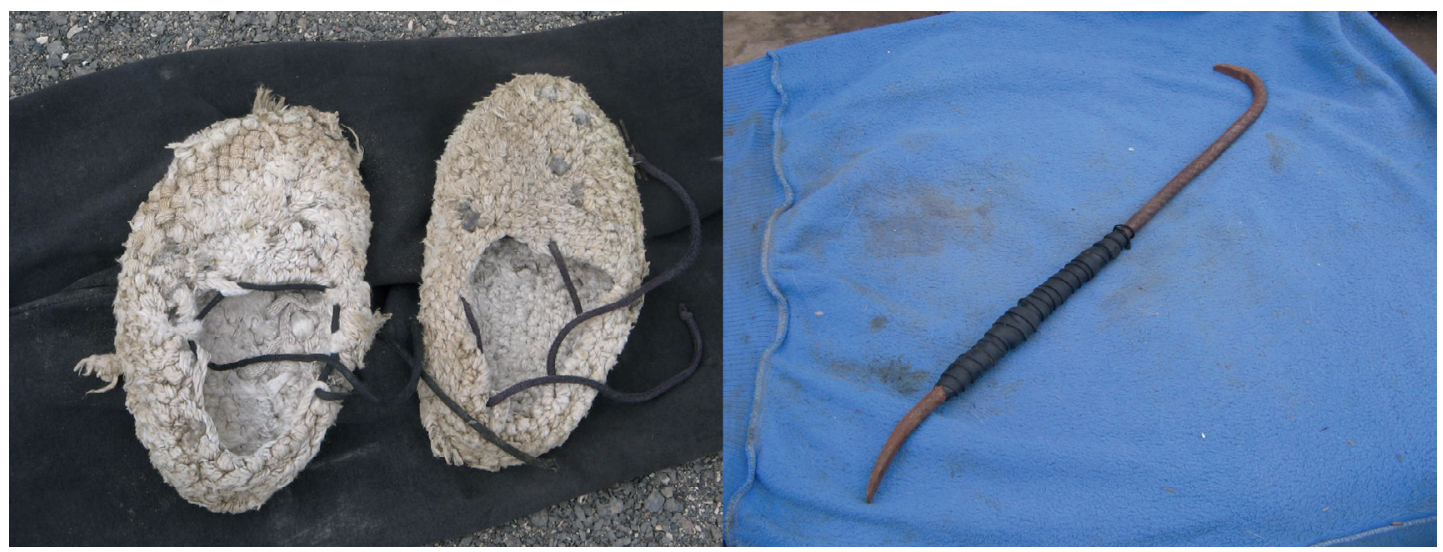

Figura 3. Changas (calzado especial) y chope (gancho para la extracción de moluscos).

Changas (special footwear) and Chope (hook for extracting molluscs).

los cangrejos que luego sirven de cebo. El otro es el cebador de un metro y $30 \mathrm{~cm}$ que en una punta lleva amarrado un anzuelo grande, donde se clava el cangrejo y en la otra tiene una empuñadura de goma. Es el más largo, pues se introduce en las cuevas donde se esconde el pulpo y permite tomar una distancia apropiada para que el animal no te vea y se espante. El tercer fierro es el pulpero que mide aproximadamente un metro y tiene una punta curva y aguzada, y en el otro extremo una empuñadura 


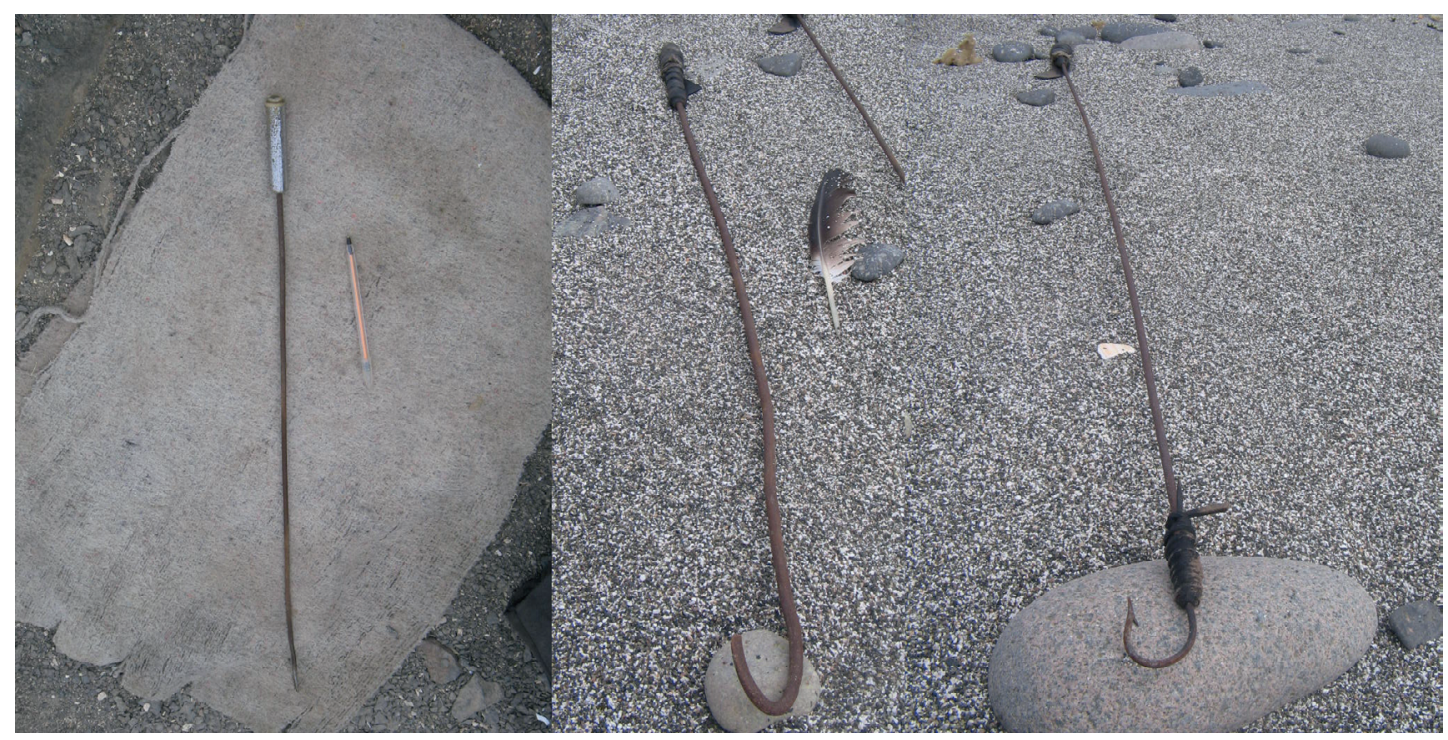

Figura 4. Cangrejero (herramienta para la captura de cangrejos), pulpero (herramienta para la captura de pulpos) y cebador (herramienta para cebar).

Cangrejero (tool for trapping crabs), pulpero (tool for trapping octopus) and cebador (tool for bait).

(Figura 4). Es muy interesante observar las grandes similitudes de estos implementos, incluyendo al chinguillo, con los artefactos arqueológicos de las colecciones costeras; obviamente existen diferencias -la expresión de las transformaciones de cada generación y sus contextos-, pero se logran concebir nociones tecnológicas generales, adecuadas a los comportamientos de las especies y a las condiciones del océano, que sustentan la variabilidad en la fabricación. También son muy significativos los nombres chinguillo y chope, pues a pesar de que no sean claras sus etimologías, son palabras específicas de la costa.

\section{Fragmentos del relato de las jornadas}

Eso de que el agua acá es más tibia es discutible. Por lo menos los dedos gordos de los pies ya no los siento. Me agacho frente a una cueva que parece de pulpo, acerco el cebador. Sale un tentáculo y abraza el cangrejo, después otro, siento el peso del animal en el cebador y la emoción que alerta para matar. Lo arrastro a la salida de la cueva y comienzo a ver el resto de su cuerpo que se enreda sobre el cebo. Acerco lentamente el pulpero hasta quedar cerca. Lo meto y saco rápido intentando enganchar al pulpo. Fallo en el intento. El pulpo suelta el cebo y se esconde en la cueva. Vuelvo a respirar.
Busqué a don Manuel a las 9 de la mañana como me había dicho. Terminamos saliendo como a las 10 , después de que tomara desayuno y que bajara la marea, lo que corroboraba observando cómo estallaba la espuma en las rocas de Punta Castilla, señal que por supuesto yo no lograba leer. Tomamos las bicicletas, cargamos los implementos para el pulpeo y partimos, yo detrás de él y sus seis perros. Nos dirigimos hacia las playas del sur de Cobija, en dirección a Punta Guasilla. Allí nos detenemos junto a una roca que hay en la playa. Don Manuel dice que es su refugio. Tiene ahí una bandeja con algunas cosas como recipientes de plástico y parte de la ropa para trabajar, el pantalón y unas poleras. Después va a cangrejear, a capturar los cangrejos que luego utilizará como carnada. Lo acompaño. Salta de una roca a otra y persigue a los cangrejos que rápidamente corren a esconderse. Aquí otra expresión de sus conocimientos: logra reconocerlos a través del agua, donde yo solo veo rocas y algas. Los clava con el cangrejero y luego los golpea para que mueran, los va metiendo en el chinguillo. Después de recolectar unos diez o doce, dice que nos vamos. Volvemos al refugio donde saca del borde de la roca un pedazo de alfombra. La estira y comienza a cambiarse de ropa sobre ella. Pantalones, polera, calcetines, soquetes de buzo y las changas. Se amarra el chinguillo a la cintura. Tomamos las bicicletas 
y seguimos avanzando hacia el sur, hacia la última playa, llamada El Mulato. Dejamos las bicicletas en la parte alta y bajamos a la playa (Figura 5). Ahí, don Manuel ve hartos huiros varados y comienza a juntarlos y amontonarlos, me dice que para venir a buscarlos luego. Cuando termina con eso, se dirige

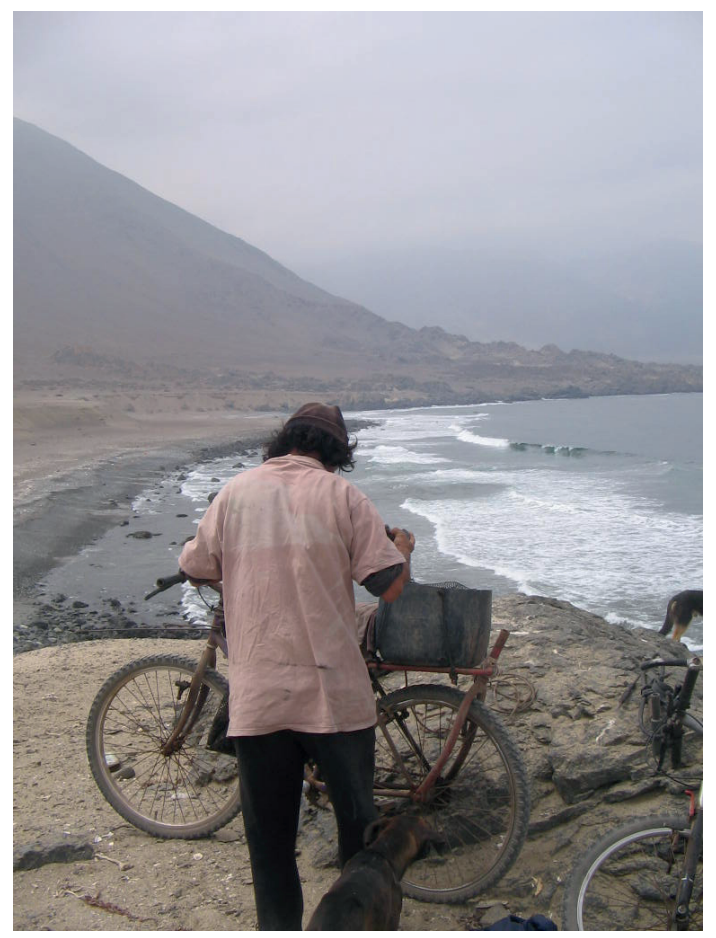

Figura 5. Parte alta playa el Mulato. Top of El Mulato beach. hacia el norte por los roqueríos, pulpeando. Yo lo acompaño y observo. Recorrimos esos roqueríos un par de horas. Se acerca a las cuevas donde podría haber pulpos (Octupus mimus). Le pregunto cómo sabe en cuál puede haber y me dice que se fija en las piedrecillas de la entrada, si están movidas o si hay algunas conchas, son signos de que la cueva está ocupada. ¿Ves? Claramente no y me quedo pensando en cómo los conocimientos que maneja pueden ser tan específicos y sutiles, y cuántos, por lo mismo, los foráneos no podemos reconocer. Mueve en la entrada el cebador con el cangrejo en la punta. De repente unos tentáculos se asoman y toman el cebo, lo envuelven con el resto de los tentáculos y don Manuel se lo va alejando para que saque todo el cuerpo de la cueva. Cuando ya está lo suficientemente afuera, acerca lentamente el pulpero y en forma rápida y precisa lo engancha y saca de un tirón. Ya atrapado, mueve y tensa los tentáculos. Lo pone en una roca y le pega con el pulpero en la cabeza para aturdirlo (Figura 6). Una vez que ya no se mueve ágilmente, lo toma y echa dentro del chinguillo que lleva en la cintura (Figura 7). Después volvimos a la playa de Punta Guasilla, donde está el refugio. Ahí siguió pulpeando una hora aproximadamente y cazó unos cuatro o cinco más.

Luego nos cambiamos de ropa, arreglamos las cosas y nos preparamos para partir. Cada vez que lo acompañé a orillar, antes de irnos arreglaba la carga de la jornada sobre su bicicleta, metía los pulpos (Octupus mimus) en un recipiente, acomodaba el chinguillo con las lapas (Fissurella ssp.) y partíamos
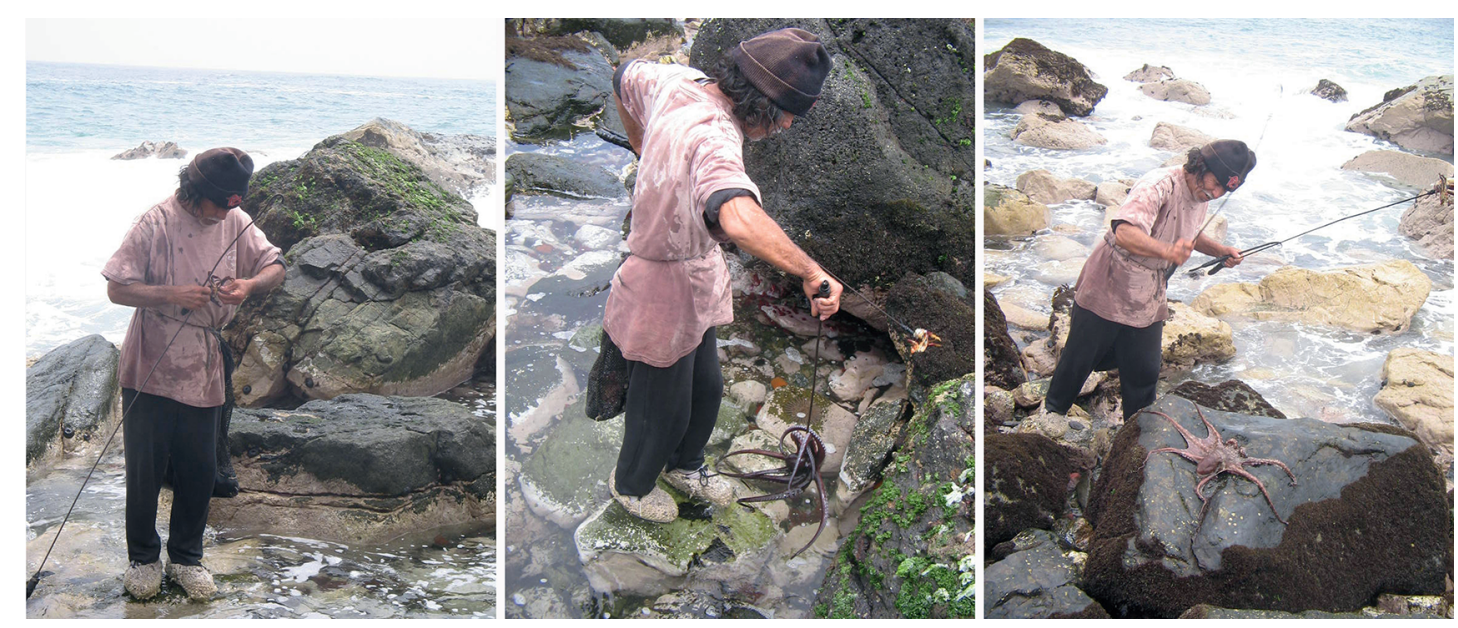

Figura 6. Cazando pulpo.

Hunting octopus. 

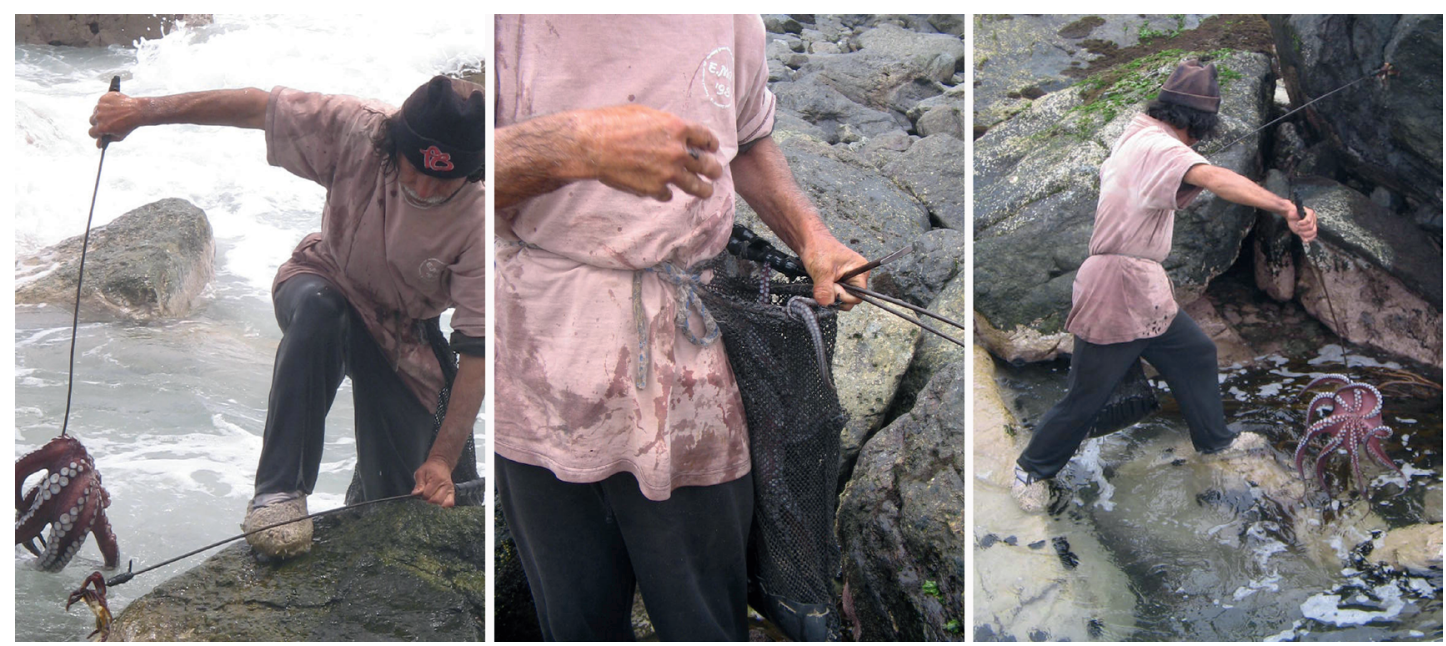

Figura 7. Cazando pulpo y guardándolo en el chinguillo.

Hunting octopus and keeping it into the chinguillo.

a Cobija. Tengo el recuerdo de quedarme mirando el movimiento agonizante de los tentáculos del pulpo que iba encima de los demás. Veinte minutos después estábamos entremedio de buzos, esperando el turno para que el rematador ${ }^{6}$ le pesara sus capturas e hiciera el cálculo del dinero correspondiente, que luego se anotaba en un cuaderno. Después el dinero se lo entregaban directamente, aunque también podía ser reemplazado por compras que don Manuel necesitara y que el rematador, que va diariamente a Tocopilla a vender las capturas, le puede comprar, permitiéndole ahorrarse un viaje a la ciudad ${ }^{7}$.

\section{Las difusas conexiones del aprendizaje}

Conocer cómo los actuales habitantes -por lo general inmigrantes o descendientes de la inmigración minera- habían logrado adoptar y reproducir las prácticas que sostienen el modo de vida costero, era necesario para determinar si el proceso se reducía a una incorporación de técnicas donde no existía una herencia reconocible, o si mantenían algún vínculo con lo creado por las poblaciones históricas y por medio de ellas con las preeuropeas. Y si era así, poder reflexionar acerca de cómo las poblaciones sin una ascendencia indígena local habían incorporado esos saberes. Sin embargo, esta fue una tarea difícil. En los relatos, tanto de don Manuel como de otros costeros, no había una persona y momento particular, sino que eran varios instantes descritos ambiguamente, otorgando al aprendizaje autodidacta y a los contactos individuales un rol central, cuestión que tenía un peso, pues era evidente que la experiencia personal generaba una acumulación de conocimientos específicos, pero también parecía evidente que por muy individuales que fueran surgían de unas nociones tecnológico-prácticas de carácter estructural. A veces identificaban al padre u otros familiares como "enseñadores", lo que no satisfacía mi curiosidad, pues eran sujetos con la misma condición de inmigración, que no permitía profundizar en el seguimiento de la transmisión de saberes costeros. Durante los terrenos insistí, hasta que en los relatos comenzaron a aparecer viejos orilleros -viejos cuando ellos eran niños-, identificados como originarios de esas costas e incluso "primitivos", que sacaban pulpos con la mano o con un solo fierro y que se metían calatos a mariscar. Y aunque no podía, ni era relevante saber que tuvieran algo de ascendencia indígena, el valor de su presencia en la historia oral estaba dada por la mayor profundidad temporal que alcanzaban las prácticas y modo de vida costero estudiados, pues eran sujetos que no pertenecían a la generación de don Manuel y sus pares, sino incluso anteriores a la de sus padres y a la etapa del proceso de inmigración que ellos representaban. Por eso era muy relevante que aparecieran en la memoria como los que estaban al momento de la llegada, lo que proyectado a las condiciones socioculturales de ese entonces, que 
hacían de la realidad cultural un campo un tanto más homogéneo, los acercaba más a una autoría de larga data, a la herencia de lo que devino de las poblaciones costeras originarias. En este sentido, es decisiva la información documental sobre los costeros del período inmediatamente anterior -principios del siglo XX o finales del XIX-, y del inicio de la segunda mitad del siglo XIX, cuando se intensifica el proceso de inmigración minera, con anterioridad guanera (Pinto y Valdivia 1994), pues a pesar que se les retrata -unilateralmentecomo sujetos social y culturalmente deprimidos, el hecho de que sigan apareciendo vinculados a la subsistencia marina implica que los conocimientos estaban disponibles para los inmigrantes que se transformaron en costeros.

\section{Caracterización del Orillero y una Propuesta}

Aunque la mayoría de los pormenores con los que se construye este trabajo están sujetos a lo que don Manuel accedió a mostrarme, también amplié mis conocimientos con otros orilleros y con relatos de personas cercanas a ellos. De esta forma, establecí puntos de vista que me parecen relevantes para caracterizarlos. Lo primero, como ya se ha expuesto, es que se trata de personas que no tienen una ascendencia étnica con los pueblos originarios de esta zona. En este sentido, lo interesante es que pudieron acceder y transmitir algunas concepciones tecnológicas y prácticas ligadas al mar y sus recursos, que los grupos marítimo-costeros elaboraron durante miles de años y que lograron mantener durante los períodos históricos. Sin embargo, esta idea requería concebir más concretamente cómo se pudieron haber adquirido esos saberes, proceso que las distinciones que hace Ingold (2001 [1996]) me ayudaron a comprender y teorizar mejor. Para él, hay dos cosas que precisar en cómo aprenden los cazadores su oficio. Primero, que no hay un código de procedimientos explícito, que fije los movimientos a ejecutar en distintas circunstancias. Y segundo, que no es posible separar en la práctica la relación del novicio con otras personas, de su relación con el medio ambiente no humano. Propone que ese know-how se obtiene por observación e imitación. Observar es atender activamente las acciones de otros y no incorporar una copia de informaciones específicas; e imitar es alinear esa atención con el movimiento de la propia orientación práctica hacia el medio ambiente. De esta forma, plantea que el enlace de percepción y acción se comprende mejor como un proceso de habilitación que como uno de enculturación, ya que "no se trata de una transmisión de representaciones, como implica el modelo de enculturación, sino de una educación de la atención" (Ingold 2001 [1996]:55). Con esta distinción puedo interpretar que no es necesario el respaldo de toda una cultura y sus representaciones para transmitir conocimientos técnicos, pues al basarse en la educación de la atención dependen mucho de la relación que el "enhabilitado" tiene con el medio ambiente y de cómo es capaz de desplegar lo que observó e imitó en un momento dado, más que con la pertenencia a un grupo específico. Puedo deducir entonces que los viejos cazadores recolectores de las últimas familias changas se fueron mezclando con las poblaciones allegadas, encontrando unos cuantos aprendices que optaron por la abundancia marina y por su consiguiente autosuficiencia, para lograr que esas nociones persistieran y fueran traspasadas a las siguientes generaciones de orilleros. Mientras las sociedades originales desaparecían, la reutilización de sus modos de subsistencia aseguró un tipo de vida paralelo a las necesidades que comenzaron a tener los nuevos pobladores de la costa. Además es necesario destacar que los orilleros también han ido reformulando esos conocimientos adquiridos y esa reformulación está asociada a otra característica importante: su vinculación permanente con los elementos y dinámicas de la sociedad contemporánea. La mayoría de ellos, de los que supe y conocí, han sido criados en los pueblos o ciudades de la zona, siendo partícipes tanto del legado costero como del sistema de educación estatal, de los procesos históricos ${ }^{8}$, o de las modas que los iniciales medios de comunicación de masas traían desde el centro. Ya en la adultez, en algún momento deciden echar mano de las técnicas y modo de vida aprendidos en la niñez, y de esa forma aprovechar la potencialidad de su independencia (relativa), para así no estar completamente inmersos en redes sociales que no les acomodaban -de ahí el vínculo con la posibilidad de análisis desde la exclusión social antes enunciada-. Sin embargo, el haber sido criados y hecho gran parte de sus vidas en los centros urbanos, los ligan a esos ambientes. De igual modo, está el ya comentado factor económico en esta relación. La subsistencia, si bien se nutre de la recolección y la caza, finalmente es convertida en dinero para comprar víveres y satisfacer otras necesidades 
que los hacen parte de las dinámicas del mercado. Ahora bien, esto que parece ser contradictorio, ha sido fuente de transformación de las técnicas de recolección y caza, y debe ser destacado, pues ha permitido la durabilidad de este modo de vida. Por ejemplo, la demanda de pulpo (Octopus mimus) por las industrias conserveras en los años ochenta generó la necesidad de hacer más eficaz su captura, lo que produjo un cambio significativo en la técnica, que fue el paso de uno a dos fierros para cazarlo (Escobar 2007:118-120), así como también la incorporación de medios de movilización como la bicicleta, los que han logrado hacer más eficiente la producción y por tanto la obtención de dinero. Es muy probable que sin esas transformaciones el modo de vida orillero ya hubiese desaparecido, pues no sería sustentable. Es posible entonces, desde mi perspectiva, proponer que las transformaciones en las técnicas de subsistencia, independientemente que sean motivadas por el mercado, hace que los orilleros no sean solo depositarios de un cúmulo de conocimientos, sino que se conviertan en integrantes activos de la tradición desértica costera. Propuesta que se apoya en dos reflexiones. Los análisis no pueden ser tan circunstanciados, sino que deben ser aprehendidos desde la larga duración propuesta por Braudel (1970), y junto a esto, considerar que las tradiciones no son un conjunto estático de saberes y representaciones, sino que por el contrario, son entidades dinámicas, expuestas a los sucesos socioculturales en las que se encuentran insertas (Boccara 1999).

Por último, los datos establecidos en esta investigación no solo han pretendido comprender el modo de vida de un orillero, sino que también aportar a la reflexión sobre las herencias culturales de larga data y su presencia muchas veces soslayada, siendo esta investigación un inicio más bien descriptivo. Es por eso que la atención de este trabajo no se concentra en la etnicidad, ni en discursos contingentes sobre continuidad, sino que apunta a resaltar las condiciones de vida de sujetos sin certezas de ese tipo, inscribiéndose analíticamente en los intentos por describir cómo operan, consciente o inconscientemente, las elecciones que guían sus prácticas. De todas maneras, esto implica necesariamente conocer el legado cultural indígena y su devenir, y a pesar de las dificultades, tratar de apreciar cómo lo hemos reutilizado en nuestra compleja y heterogénea formación como sujetos nacionales, que siempre ligada a concepciones foráneas, poco interés le ha puesto.

Agradecimientos: A don Manuel, sin su paciencia y generosidad este trabajo no existiría. A Ricardo Olivares. A la familia Pinto, la señora Blanca, María y Danilo. A Victoria Castro, por su continuo apoyo. $\mathrm{Y}$ a los evaluadores del manuscrito por sus valiosas observaciones. Este trabajo es fruto de los proyectos FONDECYT 1050991 y 1100951.

\section{Referencias Citadas}

Aldunate, C., V. Castro y V. Varela 2008. San Bartolo y Cobija: Testimonios de un modo de vida minero en las tierras altas y la costa de Atacama. Estudios Atacameños 35:97-118.

Arce, I. 1997 [1930]. Narraciones Históricas de Antofagasta. Autoedición, Fondo Nacional de Desarrollo Regional, I. Municipalidad de Antofagasta, Antofagasta.

Bermúdez, O. 1962. Una compañía para el comercio de Chile con Charcas y Potosí en el siglo XVIII. Boletín de la Academia chilena de la Historia 67:144-152.

Bermúdez, O. 1966. Orígenes Históricos de Antofagasta. I. Municipalidad de Antofagasta, Santiago.

Bermúdez, O. 1967. Perfil histórico de Cobija. Boletín de la Asociación de Geógrafos de Chile 3:3-5.

Bittmann, B. 1977. Notas sobre poblaciones de la costa del norte grande chileno. En Aproximación a la Etnohistoria del Norte de Chile y Tierras Adyacentes, editado por J.M. Casassas, pp. 56-115. Universidad del Norte, Antofagasta.
Bittmann, B. 1979. Cobija y sus alrededores en la época colonial (1600-1750). Actas del VII Congreso de Arqueología de Chile Vol. 2, pp. 327-364. Kultrún Ediciones, Santiago.

Bittmann, B. 1980. Cobija: Proyecto de Investigaciones Interdisciplinarias en la Costa Centro Sur Andina (Chile). Departamento de arqueología Universidad del Norte, Antofagasta.

Bittmann, B. 1983. Cobija: panorama etnohistórico en relación a los informes del Dr. José Agustín de Arze. Chungara 10:147-153.

Bittmann, B. 1984a. El proyecto Cobija: Investigaciones antropológicas en la costa del desierto de Atacama (Chile). Actas Simposio Culturas Atacameñas XLIV Congreso Internacional de Americanistas, pp. 99-146. Universidad del Norte, Antofagasta.

Bittmann, B. 1984b. El programa Cobija: investigaciones antropológico-multidisciplinarias en la costa centro sur andina: notas etnohistóricas. En Contribuciones a los Estudios de los Andes Centrales, editado por S. Masuda, pp. 101-149. Universidad de Tokio, Tokio. 
Boccara, G. 1999. Antropología diacrónica. Dinámicas culturales, procesos históricos y poder político. En Lógica Mestiza en América, editado por G. Boccara y S. Galindo, pp. 11-59. Instituto de Estudios Indígenas, Temuco.

Bourdieu, P. 2007 [1980]. El Sentido Práctico. Siglo XXI editores, Buenos Aires.

Braudel, F.1970. La larga duración. En La Historia y las Ciencias Sociales, editado por F. Braudel, pp. 60-106. Alianza Editorial, Madrid.

Bravo, C. 2000. La Flor del Desierto. El Mineral de Caracoles y su Impacto en la Economía Chilena. Ediciones DIBAM. LOM Ediciones, Santiago.

Cajías, F. 1975. La Provincia de Atacama. 1825-1842. Instituto Boliviano de Cultura Empresa Editora Universo, La Paz.

Cañete y Domínguez, P. 1791. Guía Histórica, Geográfica, Física, Política, Civil y Legal del Gobierno e Intendencia de la Provincia de Potosí. Archivo y Biblioteca Nacionales de Bolivia.

Casassas, J.M. 1974. La Región Atacameña en el Siglo XVII. Universidad del Norte, Antofagasta.

Castro, V. 2009. De Ídolos a Santos. Evangelización y Religión Andina en los Andes del Sur. Dirección de Bibliotecas, Archivos y Museos, Santiago.

Castro, V., C. Aldunate y V. Varela 2012. Paisajes Culturales de Cobija, costa de Antofagasta, Chile. Revista Chilena de Antropología 26:97-128.

D’Orbigny, A. 1945 [1844]. Viaje a la América Meridional. Editorial Futuro, Buenos Aires.

Escobar, M. 2007. Orillero en Cobija. Cazador Recolector Contemporáneo. Memoria para optar al título de Antropólogo Social Departamento de Antropología, Universidad de Chile, Santiago.

Fifer, V. 1976. Bolivia. Traducido por S. Aguirre. Editorial Francisco de Aguirre, Buenos Aires.

Flores, N., J. Rivera y F. Rivera 2005. El Ayer de Cobija y Gatico. Presencia de la Iglesia Católica. Ediciones Universitarias Universidad Católica del Norte, Antofagasta.

Feuillée, L. 1714. Journal des Observations Physiques, Mathematiques et Botaniques. P. Giffart Libraire, Paris.

Frezier, M. 1902 [1716]. Relación del Viaje por el Mar del Sur. Traducido por N. Peña. Imprenta Mejía, Santiago.

Hidalgo, J. 1978. Incidencias de los patrones de poblamiento en el cálculo de la población del Partido de Atacama desde 1752 a 1804. Las revisitas inéditas de 1787-1792 y 1804. Estudios Atacameños 6:53-111.

Hidalgo, J. 1983. Dos documentos inéditos y un mapa de Cobija: informes del comisionado Dr. José Agustín de Arze, 1786-1787. Chungara 10:139-145.

Hidalgo, J. 2009. Corregidores ilustrados en el desierto de Arica, Tarapacá y Atacama 1760-1780. Boletín de la Academia Chilena de la Historia118:91-155.
Hidalgo, J., N. Hume, M. Marsilli y R. Correa 1992. Padrón y revisita de Atacama del corregidor Alonso de Espejo, ordenada por el virrey Duque de la Plata, 1683. Estudios Atacameños 10:81-125.

Ingold, T. 2001 [1996]. El forrajero óptimo y el hombre económico. En Naturaleza y Sociedad: Perspectivas Antropológicas, editado por P. Descola y G. Pálsson, pp. 37-59. Editorial Siglo XXI, Ciudad de México.

Juan, J. y A. de Ulloa 1826. Noticias Secretas de América. Imprenta R. Tylor, Londres.

Larraín, H. 1978. Análisis Demográfico de las Comunidades de Pescadores Changos del Norte de Chile en el Siglo XVI. MA Dissertation, State University of New York, New York.

Latcham, R. 1910. Los Changos de las Costas de Chile. Imprenta Cervantes, Santiago.

Llagostera, A. 2005. Culturas costeras precolombinas en el norte chileno: secuencia y subsistencia de las poblaciones arcaicas. En Biodiversidad Marina: Valoración, Usos y Perspectivas ¿Hacia dónde va Chile?, editado por E. Figueroa, pp. 107-148. Editorial Universitaria, Santiago.

Lozano, J. 1885 [1581]. Carta del Factor de Potosí Juan Lozano Machuca al Virrey del Perú, en donde describe la Provincia de los Lipes de Diciembre de 1581. En Relaciones Geográficas de Indias Tomo II, pp. xxi-xxviii. Impresora de la casa real, Madrid.

Martínez, J.L. 1985. Información sobre el comercio de pescado entre Cobija y Potosí, hecha por el Corregidor de Atacama, don Juan de Segura (19 de julio de 1591). Cuadernos de Historia 5:161-171.

O'Connor, F. 1928. Reconocimiento del litoral de Atacama en 1826. Revista Chilena de Historia y Geografía 62:267-285.

Pernoud, R. 1990 [1942]. América del Sur en el siglo XVIII. Misceláneas Anecdóticas y Bibliográficas. Traducido por M. Pizarro e I. Pizarro. Fondo de Cultura Económica, México, D.F.

Philippi, R. 1860. Viage al Desierto de Atacama. Librería de E. Antón, Halle.

Pinto, J. y V. Valdivia 1994. Peones chilenos en tierras bolivianas. La presencia laboral chilena en Antofagasta: 1840-1879. Población y Sociedad 2:103-132.

Sahlins, M. 1972 [1968]. Las Sociedades Tribales. Editorial Labor, Barcelona.

Sahlins, M. 1983 [1974]. Economía de la Edad de Piedra. Traducido por E. Muñiz y E. Fondevill. Editorial Akal, Madrid.

Service, E. 1973 [1966]. Los Cazadores. Editorial Labor, Barcelona.

Vicuña, B. 1880. Historia de la Campaña de Tarapacá. Desde la Ocupación de Antofagasta hasta la Proclamación de la Dictadura en el Perú. Rafael Jover editor, Santiago.

Wallerstein, I. 2006 [2004]. Análisis de Sistemas-Mundo. Una Introducción. Traducido por C. Schroeder. Siglo XXI Editores, México, D.F. 


\section{Notas}

1 Algunos costeros me han contado que es una abreviación de telegrafista, ya que al monitorear al buzo con la cuerda a la que va amarrado mediante tirones, emula telegramas.

2 Es necesario distinguir al orillero de los llamados huireros, personas de distintas procedencias que únicamente recolectan huiro, por lo general sin ningún vínculo con conocimientos marítimo-costeros más específicos, pues únicamente persiguen una ganancia monetaria, que puede ser solo temporal.

3 Según Bittmann (1979), esta cantidad es de 30 hombres, diferencia que puede deberse a errores de impresión de las fuentes que acá se citan o las que ella utiliza. Sin embargo, lo interesante de esta diferencia, es que si bien 30 personas se acercan a las cifras de las revisitas citadas, una población de 300 personas puede ser representativa de la población total de Cobija, que las revisitas pueden no mostrar debido a la movilidad de las sociedades costeras. Sobre todo si consideramos que Frezier (1902 [1716]:141) indica que habían 50 habitaciones de indios, que para Bittmann (1979:343) podrían implicar 200-250 personas.

4 Asunto expuesto por Casassas (1974:36) aunque únicamente en referencia al texto de Latcham. Agregó además a Cañete y Domínguez (1791:271), pues en medio de su descripción de Cobija nombra al puerto de Atacama como si fuera otra entidad, lo que a lo menos refuerza la duda.

5 Spencer Tunick, fotógrafo estadounidense que se hizo conocido a nivel nacional por sus fotografías de desnudos masivos en Santiago.

6 El rematador es la persona que le compra a los pequeños productores y luego vende a comerciantes más grandes o a las conserveras.

7 Trato común entre rematadores y costeros, similar a la llamada habilitación, que en otros lugares he visto entre los dueños de embarcación y los pescadores que la trabajan. Habilitan con víveres y materiales para el trabajo, lo que se descuenta luego de lo ganado. Denominación que al parecer tiene su origen en la minería, donde también es común su uso.

8 Por ejemplo, estando en Gatico don Manuel miró lo que queda de un muelle y recordó a Fidel Castro saltando desde ahí hacia la playa, cuando estuvo en el Norte en su visita del año 1971. O también el recuerdo de las salitreras en su niñez. 